\title{
Left atrial contractile strain is the independent predictor of LV remodeling after ST-segment elevation myocardial infarction
}

\author{
Krzysztof P Karwat ${ }^{1 *}$, Marek Tomala ${ }^{2}$, Karol Miszalski-Jamka ${ }^{3}$,Wojciech Mazur ${ }^{4}$, Dean J Kereiakes ${ }^{4}$, Jadwiga Nessler ${ }^{1}$, \\ Krzysztof Zmudka², Tomasz Miszalski-Jamka,
}

From 18th Annual SCMR Scientific Sessions

Nice, France. 4-7 February 2015

\section{Background}

There is growing evidence on the value of left atrial function assessment in cardiac magnetic resonance (CMR) in patients with heart failure. However, there is paucity of data regarding the value of left atrial function in CMR to predict left ventricular remodeling in patients with STsegment elevation myocardial infarction (STEMI).

\section{Methods}

One hundred one (79 males, 22 females, mean age $58.3 \pm 11.5$ years) patients, who underwent CMR 3-5 days and 6 months after first STEMI treated with primary percutaneous coronary intervention, were enrolled. Cine, T2-weighted STIR and late gadolinium enhancement (LGE) CMR images were assessed off-line using dedicated software (QMass 7.5, Medis, Leiden, The Netherlands). Feature tracking cine-sequence based left atrial strain were measured using Diogenes CMR (TomTec Imaging Systems, Munich, Germany) in 2- and 4-chamber views. Segmental strain values were averaged from two views to obtain average reservoir, conduit and contractile strain. Logistic regression analysis was performed in stepwise forward fashion to determine CMR predictors of LV remodeling. The outcomes were expressed by odds ratio (OR) with corresponding 95\% confidence interval (CI).

\section{Results}

52 subjects had anterior and 49 inferior STEMI. LV remodeling (increase in LV end-systolic volume by $15 \%$ in 6 months after STEMI) was present in 29 subjects. Comparing subjects with and without LV remodeling

'Department of Coronary Disease and Heart Failure, John Paul II Hospital, Kraków, Poland

Full list of author information is available at the end of the article the former tended to have larger extent of LVLGE $(27.9 \pm 14.3$ versus $22.2 \pm 13.8 \%$ of LV myocardium; $\mathrm{p}=0.07)$, larger extent of microvascular obstruction (MO) within LGE ( $4.3 \pm 5.3$ versus $2.2 \pm 3.1 \%$ of LV myocardium; $\mathrm{p}=0.02$ ), higher maximal levels of troponin $\mathrm{I}(147.1 \pm 122.1$ versus $91.2 \pm 72.4 \mathrm{ng} / \mathrm{ml} ; \mathrm{p}=0.006)$, CPK-MB $(691 \pm 407$ versus $363 \pm 237 \mathrm{U} / \mathrm{l} ; \mathrm{p}<0.001)$, CPK $(4943 \pm 2968$ versus $2733 \pm 1936 \mathrm{U} / \mathrm{l} ; \mathrm{p}<0.001)$, and had lower values of average left atrial reservoir strain (14.6 \pm 5.3 versus $25.1 \pm 10.0 \%$; $<<0.001)$, left atrial conduit strain $(6.3 \pm 4.3$ versus $9.1 \pm 5.4 \% ; \mathrm{p}=0.02)$ and left atrial contractile strain $(8.3 \pm 2.8$ versus $16.0 \pm 6.2 \%$; $\mathrm{p}<0.001)$. The univariative predictors of $\mathrm{LV}$ remodeling were the extent of $\mathrm{MO}$ within LGE $(\mathrm{OR}=1.14$; 95\%CI:1.011.27; $\mathrm{p}=0.02)$, maximal levels of troponin $\mathrm{I}(\mathrm{OR}=1.006$; 95\%CI:1.002-1.011; $\mathrm{p}=0.007), \mathrm{CPK}-\mathrm{MB}(\mathrm{OR}=1.004 ; 95 \%$ CI:1.002-1.010; $\mathrm{p}<0.001)$, CPK (OR=1.0004; 95\%CI:1.00021.0006; $\mathrm{p}<0.001)$, and average left atrial reservoir strain $(\mathrm{OR}=0.80 ; 95 \% \mathrm{CI}: 0.72-0.88 ; \mathrm{p}<0.001)$, left atrial conduit strain $(\mathrm{OR}=0.86 ; 95 \% \mathrm{CI}: 0.77-0.98 ; \mathrm{p}=0.01)$ and left atrial contractile strain $(\mathrm{OR}=0.62$; $95 \% \mathrm{CI}: 0.50-0.77 ; \mathrm{p}<0.001)$. Of those in multivariative analysis the independent predictors were CPK (OR=1.0003; 95\%CI:1.0000-1.0006; $\mathrm{p}=0.048)$ and left atrial contractile strain $(\mathrm{OR}=0.65 ; 95 \%$ CI:0.53-0.80; $\mathrm{p}<0.001)$.

\section{Conclusions}

LV remodeling is frequent after STEMI. The average left atrial contractile strain is the independent predictor of LV remodeling in 6 months observation.

\section{Funding}

N/A. 


\section{Authors' details}

'Department of Coronary Disease and Heart Failure, John Paul II Hospital, Kraków, Poland. ${ }^{2}$ Department of Haemodynamics and Angiocardiography, John Paul II Hospital, Kraków, Poland. ${ }^{3}$ Department of Cardiology, Congenital Heart Disease and Electrotherapy, Silesian Center for Heart Disease, Zabrze, Poland. ${ }^{4}$ The Christ Hospital Heart and Vascular Center, The Lindner Center for Research and Education, Cincinatti, OH, USA. ${ }^{5}$ Department of Radiology and Imaging Diagnostics, John Paul II Hospital, Kraków, Poland. ${ }^{6}$ Center for Heart Disease, Clinical Military Hospital, Wrocław, Poland.

Published: 3 February 2015

doi:10.1186/1532-429X-17-S1-P151

Cite this article as: Karwat et al: Left atrial contractile strain is the independent predictor of LV remodeling after ST-segment elevation myocardial infarction. Journal of Cardiovascular Magnetic Resonance 2015 17(Suppl 1):P151.

\section{Submit your next manuscript to BioMed Central} and take full advantage of:

- Convenient online submission

- Thorough peer review

- No space constraints or color figure charges

- Immediate publication on acceptance

- Inclusion in PubMed, CAS, Scopus and Google Scholar

- Research which is freely available for redistribution

Submit your manuscript at www.biomedcentral.com/submit 